\title{
Unusual association between Ornithonyssus bursa (Berlese, 1888) (Mesostigmata: Macronyssidae) and Parabuteo unicinctus (Temminck, 1824) (Accipitriformes: Accipitridae) in Paraíba State, Brazil
}

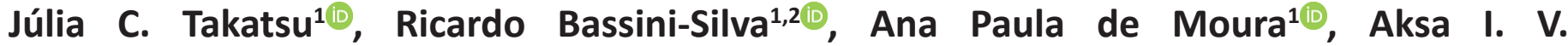 \\ Batista $^{3 \oplus}{ }^{(}$Glenison F. Dias $^{3 \oplus}$, Josivania S. Pereira ${ }^{3 \oplus}$, Ashley P. G. Dowling ${ }^{4 \oplus}$, Fernando de C. \\ Jacinavicius $\mathbf{s}^{2=-10}$ \\ ${ }^{1}$ Laboratório de Coleções Zoológicas, Instituto Butantan, São Paulo, SP, Brazil. ${ }^{2}$ Departamento de Patologia, Reprodução e \\ Saúde Única, Faculdade de Ciências Agrárias e Veterinárias-UNESP, Jaboticabal, SP, Brazil. ${ }^{3}$ Laboratório de Parasitologia Animal, \\ Departamento de Biociências, Centro de Ciências Biológicas e da Saúde, Universidade Federal Rural do Semi-Árido-UFERSA, \\ Mossoró, RN, Brazil. ${ }^{4}$ Department of Entomology \& Plant Pathology, University of Arkansas, Fayetteville, AR, USA.
}

拝=゙Corresponding author: fcjacinavicius@gmail.com

Edited by: Peterson R. Demite

Received: October 21, 2021. Accepted: October 26, 2021. Published: December 07, 2021.

\begin{abstract}
Ornithonyssus bursa (Berlese, 1888), known as the tropical fowl mite, is a hematophagous mite of domestic and wild birds. This mite can bite humans accidentally, causing "gamasoidosis," "avian-mite dermatitis," or "bird-mite dermatitis" in tropical and subtropical regions of the world. In Brazil, O. bursa was previously recorded parasitizing birds of the orders Charadriiformes Huxley, 1867, Columbiformes Latham, 1790, Galliformes Temminck, 1820, Passeriformes Linnaeus, 1758, Strigiformes Wagler, 1830, and Tinamiformes Huxley, 1872. Here, we provide a new association of $O$. bursa with Harris's hawk, Parabuteo unicinctus (Temminck, 1824) (Accipitriformes: Accipitridae) and the first record of this mite species in the Paraíba State, Brazil.
\end{abstract}

Keywords: Macronyssid, ectoparasites, Brazilian Northeast, Birds of prey.

Macronyssidae comprise approximately 240 species, organized in 34 genera. The mites included in this family are ectoparasites of reptiles, birds, and mammals (Radovsky 2010). One of these species, Ornithonyssus bursa (Berlese, 1888), known as "tropical fowl mite", is a hematophagous mite of domestic and wild birds, and can bite humans accidentally, causing "gamasoidosis", "avian-mite dermatitis", or "bird-mite dermatitis" in tropical and subtropical regions of the world (Bassini-Silva et al. 2019; Lima-Barbero et al. 2019).

In Brazil, $O$. bursa is found parasitizing birds of the orders Charadriiformes Huxley, 1867, Columbiformes Latham, 1790, Galliformes Temminck, 1820, Passeriformes Linnaeus, 1758, Strigiformes Wagler, 1830, and Tinamiformes Huxley, 1872 (Vaz 1935; Reis 1939; Ribeiro et al. 1992; Mascarenhas et al. 2009; Goulart et al. 2011; Moraes et al. 2011; Coimbra et al. 2012; Oliveira et al. 2012; Wambier \& Wambier 2012; Mentz et al. 2015; Silva et al. 2018; BassiniSilva et al. 2019; Mesquita-Sousa et al. 2020). To plot the distribution map of $O$. bursa in Brazil, we used the occurrence locations provided in the previous records, including the new record of this study (Tab. 1, Fig. 1). To search for geographic coordinates not provided in the original records, we use the "GeoLoc" online tool, from the speciesLink project, for the georeferencing of zoological collections (CRIA 2021).

Here, we are providing a new association of $O$. bursa with Harris's hawk, Parabuteo unicinctus (Temminck, 1824) (Accipitriformes: Accipitridae) in Paraíba State, Brazil. The material was collected on September 18th, 2020, from a captive adult female Harris's Hawk (Fig. 2). The animal is legally kept and used by a professional falconer to control pigeons in the João Pessoa Municipality, Paraíba State. During a demonstration of falconry techniques held at the Arruda Câmara Zoo-Botanical Park, João Pessoa, Paraíba State, an ectoparasite was noticed walking on the animal's legs. Because of this, in this short communication we prefer to use the term "mite/ bird of prey association". The ectoparasite was collected with a piece of tape and placed in a tube containing $70^{\circ}$ alcohol. This material was slide-mounted with Hoyer's medium according to Barros-Battesti et al. (2021) and deposited in the Acarological Collection of Butantan Institute (IBSP) under the access number IBSP 16533. The specimen was imaged using a Leica DFC 500 digital camera coupled to an optical microscope Leica DM4000B, in the Zoological Collection Laboratory, Butantan Institute, São Paulo. All images were prepared with Adobe Photoshop v. 13.0. According to Bassini-Silva et al. (2019), we confirm the main set of morphological characters, and the details of the sternal and distal opisthosoma shields are shown in (Fig. 3).

The Harris's Hawk is widely distributed in the America's and can be found in the open lands of the southwestern region of the United States of America to the south of Argentina (Patagonia region) (Brown \& Amadon 1968; Bednarz 1995; Couve \& Vidal 2003). This hawk preys mainly on small birds and mammals, such as wild and synanthropic doves, passerines, quails, small herons, rodents, and marsupials (Whaley 1986; Jiménez \& Jaksic 1993; Bednarz 1995).

In Brazil, the only record of $O$. bursa parasitizing birds of prey was made by Mascarenhas et al. (2009), who found a lot of this mite on the offspring of Megascops choliba (Vieillot, 1817) (Strigiformes: Strigidae), in Pelotas Municipality, Rio Grande do Sul State. This is the first report of $O$. bursa on $P$. unicinctus. The presence of this association can be important for the bird's health since the presence of this mite can cause lesions with intense pruritus, or even host mortality when population numbers are large (Coimbra et al. 2012; Mascarenhas et al. 2009).

Although this bird of prey species is considered as Least Concern (LC) on the Red List (IUCN 2021), and not threatened with extinction, its population has been declining in recent years. In addition, this kind of mite/bird of prey association may be related to this bird feeding 
Table 1. Locality and avian host-association records for Ornithonyssus bursa (Berlese, 1888) in Brazil.

\begin{tabular}{|c|c|c|c|c|}
\hline Hosts & Common names & Localities & Coordinates & References \\
\hline \multicolumn{5}{|l|}{ ACCIPITRIFORMES } \\
\hline \multicolumn{5}{|l|}{ Accipitridae } \\
\hline Parabuteo unicinctus (Temminck, 1824) & Harris's hawk & João Pessoa/PB & $7^{\circ} 06^{\prime} 54^{\prime \prime} \mathrm{S} ; 34^{\circ} 51^{\prime} 47^{\prime \prime} \mathrm{W}$ & This study \\
\hline \multicolumn{5}{|l|}{ CHARADRIIFORMES } \\
\hline \multicolumn{5}{|l|}{ Charadriidae } \\
\hline Vanellus chilensis (Molina, 1782) & Southern lapwing & São Sepé/RS & $30^{\circ} 09^{\prime} 39^{\prime \prime} \mathrm{S} ; 53^{\circ} 33^{\prime} 54^{\prime \prime} \mathrm{W}$ & Silva et al. 2018 \\
\hline \multicolumn{5}{|l|}{ Scolopacidae } \\
\hline Gallinago paraguaiae (Vieillot, 1816) & South American snipe & São Sepé/RS & $30^{\circ} 09^{\prime} 39^{\prime \prime} \mathrm{S} ; 53^{\circ} 33^{\prime} 54^{\prime \prime} \mathrm{W}$ & Silva et al. 2018 \\
\hline
\end{tabular}

\section{COLUMBIFORMES}

Columbidae

Columba livia Gmelin, 1789

Columbina picui (Temminck, 1813)

Rock dove

Picui dove

ão Paulo/SP

Pelotas/RS

São Sepé/RS

São Paulo/SP

São Sepé/RS

Dois Vizinhos/PR

Piracicaba/SP

Leptotila verreauxi Bonaparte, 185

Zenaida auriculata (Des Murs, 1847)

White-tipped dove

São Sepé/RS

São Paulo/SP

Jaboticabal/SP $23^{\circ} 32^{\prime} 52^{\prime \prime} \mathrm{S} ; 46^{\circ} 38^{\prime} 10^{\prime \prime} \mathrm{W}$

$31^{\circ} 46^{\prime} 19^{\prime \prime} \mathrm{S} ; 52^{\circ} 20^{\prime} 32^{\prime \prime} \mathrm{W}$ $30^{\circ} 09^{\prime} 39^{\prime \prime} \mathrm{S} ; 53^{\circ} 33^{\prime} 54^{\prime \prime} \mathrm{W}$

$23^{\circ} 32^{\prime} 52^{\prime \prime} \mathrm{S} ; 46^{\circ} 38^{\prime} 10^{\prime \prime} \mathrm{W}$ $30^{\circ} 09^{\prime} 39^{\prime \prime} \mathrm{S} ; 53^{\circ} 33^{\prime} 54^{\prime \prime} \mathrm{W}$ $25^{\circ} 44^{\prime} 01^{\prime \prime} \mathrm{S} ; 53^{\circ} 03^{\prime} 25^{\prime \prime} \mathrm{W}$ $22^{\circ} 43^{\prime} 32^{\prime \prime}$; ; $47^{\circ} 38^{\prime} 56^{\prime \prime} \mathrm{W}$ $30^{\circ} 09^{\prime} 39^{\prime \prime} \mathrm{S}$; 533' $54^{\prime \prime} \mathrm{W}$ $23^{\circ} 32^{\prime} 52^{\prime \prime} \mathrm{S} ; 46^{\circ} 38^{\prime} 10^{\prime \prime} \mathrm{W}$ $21^{\circ} 15^{\prime} 18^{\prime \prime} \mathrm{S} ; 48^{\circ} 19^{\prime} 20^{\prime \prime} \mathrm{W}$
Wambier \& Wambier 2012; Mesquita-Souza et al. 2020

Coimbra et al. 2012; Silva et al. 2018

Moraes et al. 2011;

Silva et al. 2018

Bassini-Silva et al. 2019;

Mesquita-Souza et al. 2020

Silva et al. 2018

Goulart et al. 2011

Bassini-Silva et al. 2019

\section{GALLIFORMES}

Phasianidae

Gallus gallus (Linnaeus, 1758)

Red junglefowl

São Paulo/SP

Viamão/RS

Rio de Janeiro/RJ

São José dos Campos/SP

\section{PASSERIFORMES}

\section{Furnariidae}

Certhiaxis cinnamomeus (Gmelin,

1788)

Furnarius rufus (Gmelin, 1788)

Hirundinidae

Progne tapera (Linnaeus, 176

Pygochelidon cyanoleuca (Vieillot,

1817)

\section{Icteridae}

Cacicus chrysopterus (Vigors, 1825)

Mimidae

Mimus saturninus (Lichtenstein, 1823)

\section{Chalk-browed}

mockingbird

Rufous hornero

São Sepé/RS

$30^{\circ} 09^{\prime} 39^{\prime \prime} \mathrm{S} ; 53^{\circ} 33^{\prime} 54^{\prime \prime} \mathrm{W}$

$30^{\circ} 09^{\prime} 39^{\prime \prime} \mathrm{S} ; 53^{\circ} 33^{\prime} 54^{\prime \prime} \mathrm{W}$

$30^{\circ} 01^{\prime} 60^{\prime \prime} \mathrm{S} ; 51^{\circ} 13^{\prime} 47^{\prime \prime} \mathrm{W}$

Porto Alegre/ RS

$23^{\circ} 32^{\prime} 52^{\prime \prime} \mathrm{S} ; 46^{\circ} 38^{\prime} 10^{\prime \prime} \mathrm{W}$

Vaz 1935; Reis 1939; BassiniSilva et al. 2019

3004'53"S; 5101'24"W Ribeiro et al. 1992

$22^{\circ} 54^{\prime} 11^{\prime \prime S}$; 4312'27"W Bassini-Silva et al. 2019

$23^{\circ} 10^{\prime} 46^{\prime \prime}$; $45^{\circ} 53^{\prime} 12^{\prime \prime} \mathrm{W}$

Bassini-Silva et al. 2019

$30^{\circ} 09^{\prime} 39^{\prime \prime} \mathrm{S} ; 53^{\circ} 33^{\prime} 54^{\prime \prime} \mathrm{W}$

Silva et al. 2018

Blue-and-white swallow Mogi das Cruzes/SP

$23^{\circ} 31^{\prime} 22^{\prime \prime} \mathrm{S} ; 46^{\circ} 11^{\prime} 17^{\prime \prime} \mathrm{W}$

Bassini-Silva et al. 2019

$30^{\circ} 09^{\prime} 39^{\prime \prime}$ S; 533' $54^{\prime \prime} \mathrm{W} \quad$ Silva et al. 2018

\section{Parulidae}

Basileuterus culicivorus (Deppe, 1830) Stripe-crowned warbler São Sepé/RS

Passerellidae

Thraupidae

Paroaria coronata (Miller, 1776)

Rufous-collared sparrow São Sepé/RS

Sicalis flaveola (Linnaeus, 1766

Red-crested cardinal

São Sepé/RS

Saffron finch

São Sepé/RS

Santa Maria/RS

\section{Troglodytidae}

Troglodytes musculus Naumann, 1823 Southern house wren Balsas/MA

$7^{\circ} 31^{\prime} 57^{\prime \prime} \mathrm{S} ; 46^{\circ} 02^{\prime} 08^{\prime \prime} \mathrm{W}$

Mesquita-Souza et al. 2020 


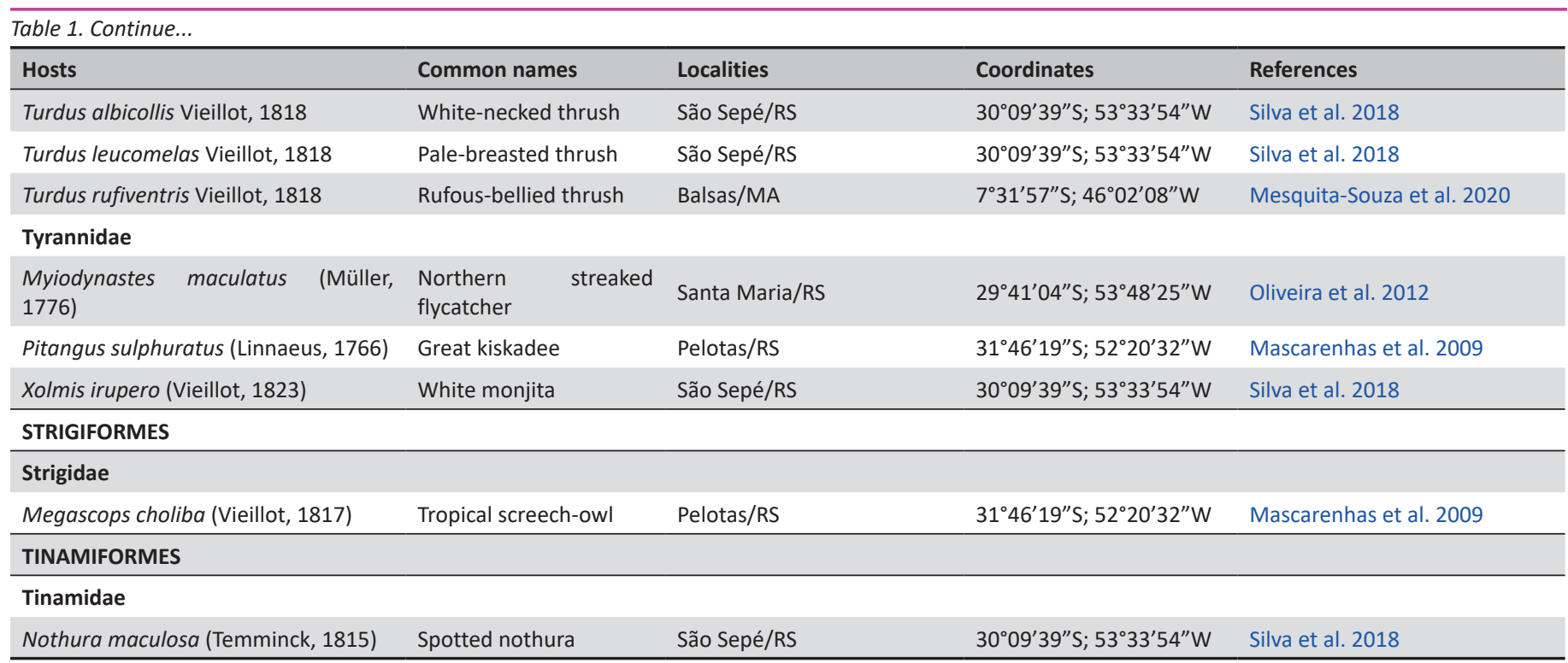

Legend. MA= Maranhão State; PB= Paraíba State; $\mathbf{R J}=$ Rio de Janeiro State; RS = Rio Grande do Sul State; SP= São Paulo State.

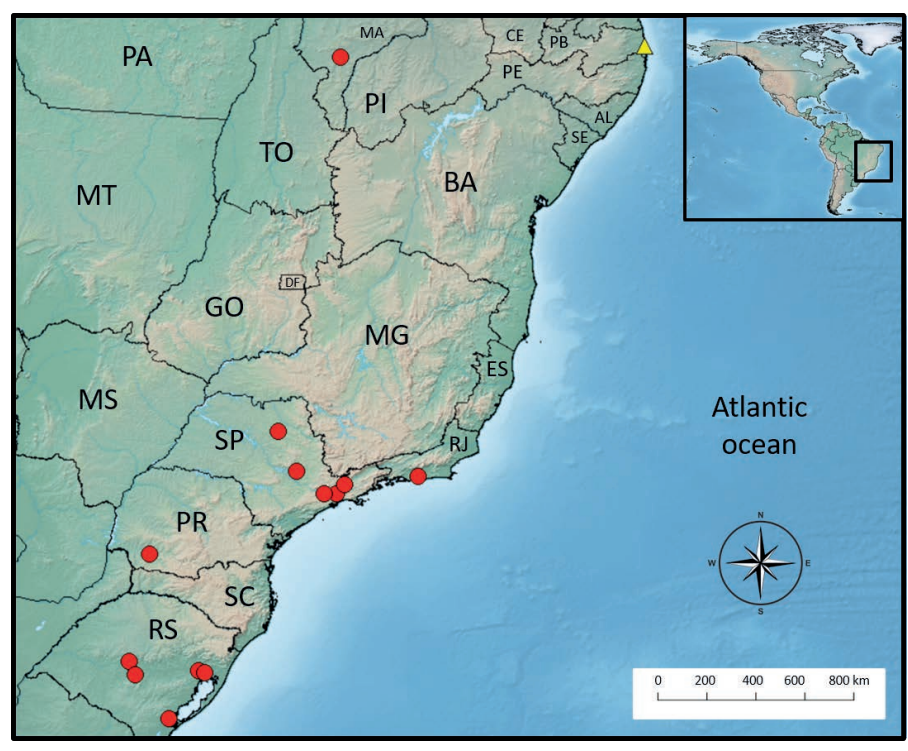

Figure 1. Distribution of Ornithonyssus bursa (Berlese, 1888) in Brazil. The red circles are literature records, while the yellow triangle is the new record.

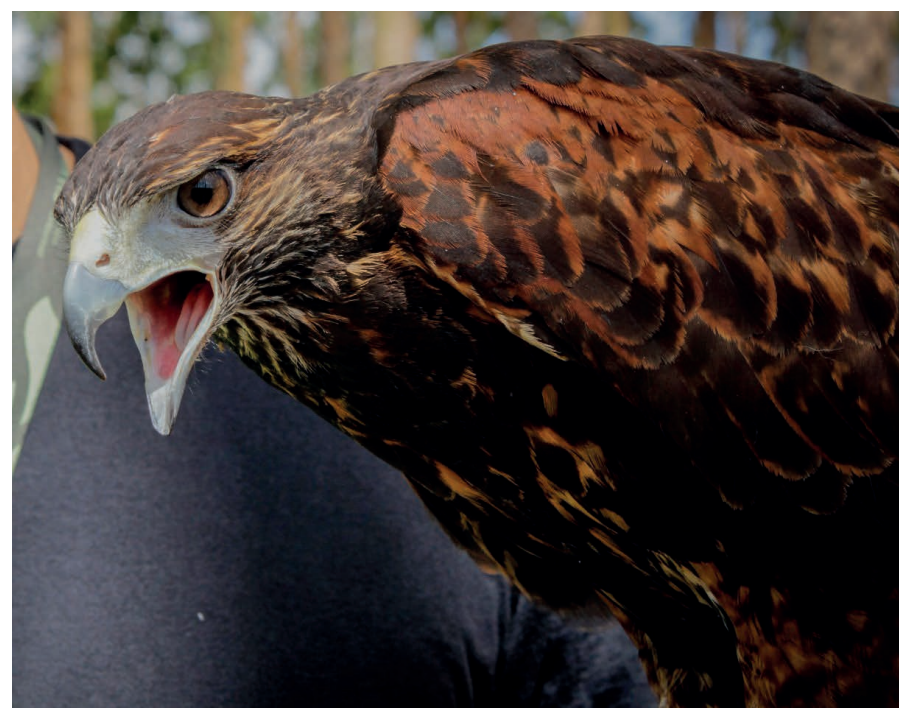

Figure 2. Adult female Harris's Hawk, Parabuteo unicinctus (Temminck, 1824) parasited by Ornithonyssus bursa (Berlese, 1888).
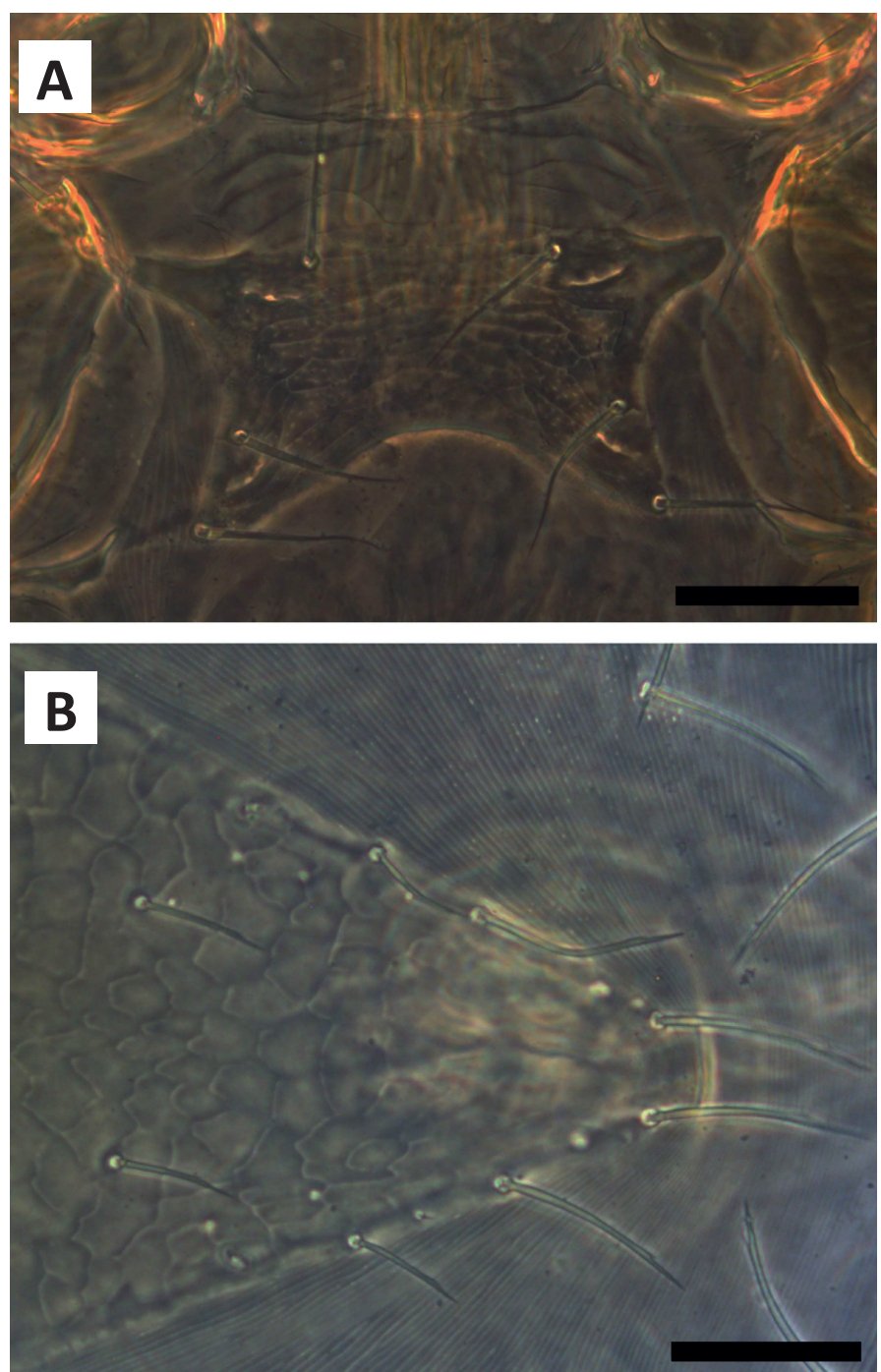

Figure 3. Female of Ornithonyssus bursa (Berlese, 1888). (A) sternal shield. (B)

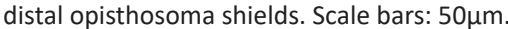


habits, which include the birds listed in Tab. 1. The hawk from this report was specifically used to control Columba livia Gmelin, 1789 (Columbiformes: Columbidae), populations, which are common hosts of $O$. bursa. This may contribute to the maintenance of these mites on other hosts, and help in dispersing these mites throughout the America's, contributing to the increase in human bite cases.

\section{Acknowledgements}

To Gabrielle Ribeiro de Andrade and Maria Cristina Ferreira do Rosário for technical contribution. This work was supported by the Fundação de Amparo à Pesquisa do Estado de São Paulo under the Grant FAPESP no. 2021/02295-4 (JCT), 2021/08179-6 (APM), 2019/198530 (FCJ), 2017/01416-7, 2018/24667-8 and 2020/11755-6 (RB-S). This study was financed in part by the Coordenação de Aperfeiçoamento de Pessoal de Nível Superior - Brasil (CAPES) - Finance Code 001.

\section{Authors' Contributions}

JSP, AIVB, and GFD collected the mite in association with the host and performed the record. FCJ, RB-S, and APGD performed the study and confirmed the identification of the mites. RS-R, JCT, and APM conducted the mite's preparations and wrote the manuscript with input from all authors.

\section{References}

Barros-Battesti, D. M.; Jacinavicius, F. C.; Bauchan, G.; Bassini-Silva, R. (2021) Chapter 24: Techniques for studies on Acariformes. In: Barros-Battesti, D. M.; Machado, R. Z.; André, M. R. (Eds.), Brazilian ectoparasite fauna of veterinary importance, Volume 1, Mite fauna of veterinary importance: Acariformes, pp. 294-303. Jaboticabal: CBPV.

Bassini-Silva, R.; Jacinavicius, F. C.; Hernandes, F. A.; Ochoa, R.; Bauchan, G. R.; Dowling, A. P. G.; Barros-Battesti, D. M. (2019) Dermatitis in humans caused by Ornithonyssus bursa (Berlese 1888) (Mesostigmata: Macronyssidae) and new records from Brazil. Revista Brasileira de Parasitologia Veterinária, 28(1): 134139. doi: 10.1590/S1984-296120180097

Bednarz, J. C. (1995) Harris' Hawk (Parabuteo unicinctus). In: Poole, A.; Gill, F. (Eds.), The birds of North America, No. 146. Philadelphia: The Academy of Natural Sciences.

Brown, L. H.; Amadon, D. (1968) Eagles, hawks and falcons of the world. Vol. 1. London: Country Life Books.

Coimbra, M. A. A.; Mascarenhas, C. S.; Müller, G.; Brum, J. G. W. (2012) Phthiraptera and Gamasida parasites of Columbina picui (Temminck) (Columbiformes: Columbidae) in the State of Rio Grande do Sul, Southern Brazilian. Brazilian Journal of Biology, 72: 583-585. doi: 10.1590/S1519-69842012000300022

Couve, E.; Vidal, C. (2003) Birds of Patagonia, Tierra del Fuego and Antarctic Peninsula, the Falkland Island and South Georgia. Punta Arenas: Fantastico Sur-Birding and Nature Tours.

CRIA (2021) Centro de Referência e Informação Ambiental. SpeciesLink project: GeoLoc. http://splink.cria.org.br/geoloc?criaLANG=pt. Access on: 18.x.2021.

Goulart, T. M.; Moraes, D. L.; Prado, A. P. (2011) Mites associated with the eared dove, Zenaida auriculata (Des Murs, 1847), in São Paulo State, Brazil. Zoosymposia. 6: 267-274.

IUCN (2021) The IUCN Red List of Threatened Species. Version 2021-2. https://www.iucnredlist.org. Access on: 18.x.2021.

Jiménez, J. E.; Jaksic, F. M. (1993) Observations on the comparative behavioral ecology of Harris' Hawks (Parabuteo unicinctus) in central Chile. Journal of Raptor Research 27: 143-148.

Lima-Barbero, J. F.; Sánchez, M. S.; Cabezas-Cruz, A.; MateosHernández, L.; Contreras, M.; de Mera, I. G. F. F.; Villar, M.; de la Fuente. J. (2019) Clinical gamasoidosis and antibody response in two patients infested with Ornithonyssus bursa (Acari: Gamasida: Macronyssidae). Experimental \& Applied Acarology, 78: 555-564. doi: 10.1007/s10493-019-00408-x
Mascarenhas, C. S.; Coimbra, M. A. A.; Müller, G.; Brum, J. G. W. (2009) Ocorrência de Ornithonyssus bursa (Berlese, 1888) (Acari: Macronyssidae) em filhotes de Megascops choliba (Corujinha-domato) e Pitangus sulphuratus (Bem-te-vi), no Rio Grande do Sul, Brasil. Revista Brasileira de Parasitologia Veterinária, 18(4): 69-70. doi: 10.4322/rbpv.01804013

Mentz, M.; Silva, G. L.; Silva, C. E. (2015) Dermatitis caused by the tropical fowl mite Ornithonyssus bursa (Berlese) (Acari: Macronyssidae): a case report in humans. Revista da Sociedade Brasileira de Medicina Tropical. 48: 786-788. doi: 10.1590/0037-8682-0170-2015

Mesquita-Sousa, D.; Viegas-Melo, D.; Martins, T. F.; Monteiro, S. G.; Faccini, J. L. H.; Labruna, M. B.; Barros-Battesti, D. M.; Bassini-Silva, R.; Soares, A. M. S.; Costa-Junior, L. M.; Luz, H. R. (2020) An overview of gamasoidosis caused by Ornithonyssus bursa (Mesostigmata: Macronyssidae) in Brazil and new case records. International Journal of Acarology, 46(7): 568-573, doi: 10.1080/01647954.2020.1810119

Moraes, D. L.; Goulart, T. M.; Prado, A. P. (2011) Mites associated with the ruddy ground dove, Columbina talpacoti (Temminck, 1810), in São Paulo State, Brazil. Zoosymposia. 6: 275-281. doi: 10.11646/ zoosymposia.6.1.37

Oliveira, C. B.; Tonin, A. A.; Monteiro, S. G. (2012) Parasitismo do ácaro Ornithonyssus bursa em humanos no Sul do Brasil. Acta Scientiae Veterinarie, 40: 1091.

Radovsky, F. J. (2010) Revision of genera of the parasitic mite family Macronyssidae (Mesostigmata: Dermanyssoidea) of the World, vol. 170. West Bloomfield: Indira Publishing House.

Reis, J. (1939) Alguns parasitos de G. gallus (L.) verificados em São Paulo. Arquivos do Instituto Biológico, 10:147-153.

Ribeiro, V. L. S.; Moojen, V.; Telles, A. P. D. (1992) Caso clínico: Ornithonyssus bursa: parasito de aves causando acaríases Arquivos da Faculdade de Veterinária da UFRGS cutâneas em humanos no Rio Grande do Sul, Brasil. Anais Brasileiros de Dermatologia. 67: 31-34.

Silva, D. E.; Silva, G. L.; Nascimento, J. M.; Ferla, N. J. (2018) Mite fauna associated with bird nests in Southern Brazil. Systematic \& Applied Acarology, 23: 426-440. doi: 10.11158/saa.23.3.2

Vaz, Z. (1935) Ectoparasitas de animais domésticos observados no Estado de São Paulo. Arquivos do Instituto Biológico, 6: 29-33.

Wambier, C. G.; Wambier, S. P. (2012) Gamasoidosis illustrated - from the nest to dermoscopy. Anais Brasileiros de Dermatologia. 87: 926-927. doi: 10.1590/S0365-05962012000600021

Whaley, W. H. (1986) Population ecology of the Harris' Hawk in Arizona. Journal of Raptor Research, 20: 1-15. 